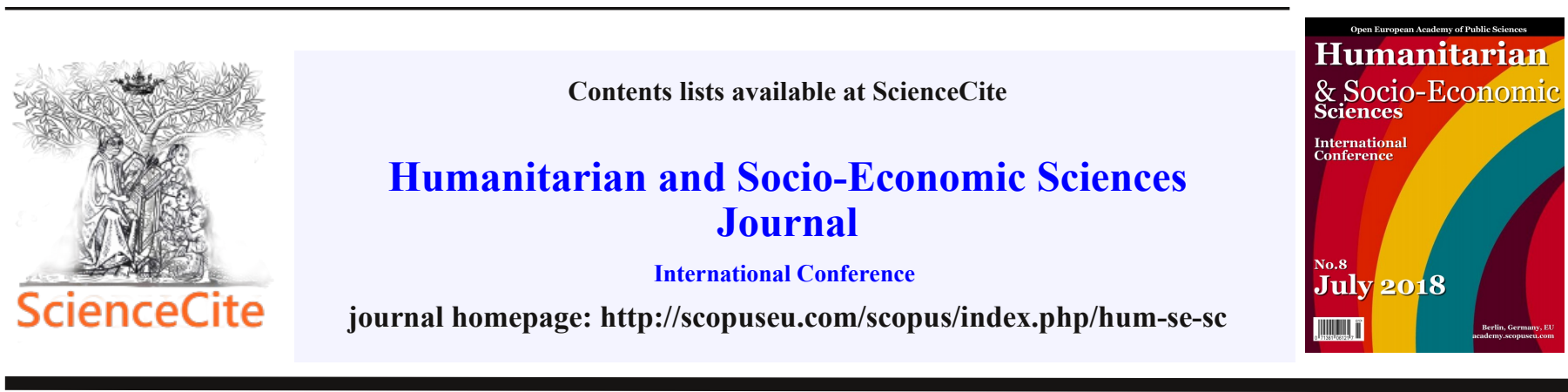

\title{
Literary duel: Barclay vs. Keats in the context of the translation of a little-known poem
}

\author{
PhD Liudmila Vyacheslavovna Fomina \\ National Technical University Dnipro Polytechnic - NTUDP \\ Dmitry Yavornitsky Avenue, 19, Dnipro, 49000, Ukraine
}

\begin{abstract}
Two interpretations of mythological plot about Endymion are investigated. The nineteenth century provides the interpretational variety of the myth about Endymion in English poetry. Keats's Endymion is a romantic character who is looking for an ideal of beauty and love embodied in the Goddess of the Moon. Barclay`s Endymion is weak-willed. His suicide symbolizes the collapse of romantic ideals in the reality of Victorianism. As for the image of the Goddess of the Moon she embodies an ideal of femininity, passion, spiritual and physical beauty in the poem by Keats. Barclay`s version depicts a pragmatic, selfish beauty, belonging to the elite society. Having enjoyed a poor shepherd's youth and his beauty she left him to live in luxury on Olympus. Barclay's interpretation is considered as a critique of romantic ideals and Romanticism on the whole. The Ukrainian (the first from the original language) translation of Barclay's interpretation about Endymion is of particular interest. The discovery of a little-known English poet Donald Hugh Barclay and an attempt to study his creation give a possibility to introduce a new name to the literature criticism.

This article opens the prospects for further consideration of literary endymionade.
\end{abstract}

Key words: Myth, Endymion, The Goddess of the Moon, Transformation, Interpretation Translation, Romanticism, Neomifologizm, Endymionade.

The research of the myth interpretations is considered to be one of the main tasks of modern comparative literary criticism $[1, \mathrm{p} .5$ 6]. The ancient sources of the myth and its reception in the Renaissance art were firstly investigated by Natalia Agapiou [2]. The first study of endymionade was researched by L. Fomina [3] in 2014. A conceptual originality of the ancient Greek myth about Endymion was considered in her work. The origins of the English endymionade (John Lily's and Michael Drayton's versions of the myth) were studied.
Moreover the functioning features of traditional mythological plot about Endymion were investigated in synchronic and diachronic approaches, the characteristics of English poetical endymionade were given in the context of various literary movements and trends of the XIX-th century (Romanticism, Aestheticism, Neoclassicism).

The purpose of this article is to attract the readers' attention to Barclay`s interpretation about Endymion which denies romantic ideals

https://doi.org/10.5281/zenodo.1318354

Received June 30, 2018; Received in revised form on July 12, 2018; Adopted on July 14, 2018

(C) 2018 The Author. Published by OEAPS Inc. This is an open access article under the CC BY-NC-ND license (http://creativecommons.org/licenses/by-nc-nd/4.0/). 
represented in Keats's poem "Endymion" and criticizes Romanticism on the whole. This problem has never been studied yet that's why it is of peculiar interest. As for the methods of investigation they are following: Comparative historical analysis of the myth sources, mythopoetic analysis of literary interpretation and an analytical method.

The name of English poet John Keats (17951821 ) is associated with Romanticism.

His poem"Endymion" (1817) [4,p.27-144] is considered to be an artistic manifestation, an expression of his aesthetic views as a romantic poet. From his point of view the poet must devote himself to the search for beauty in the world to depict it in the poems. That's why N. Ya.Berkovsky calls Keats "one of the founders of Aestheticism in Europe" [5,p.185]. Thus Keats' $s$ poem is characterized by the peculiarities of romantic art as well as the features of early Aestheticism. As for peculiarities of Romanticism in the poem they are following:

- Numerous interlinks: reminiscences, allusions and symbols of antique, medieval, Renaissance ideas, motifs, images;

- Using symbol and myth as artistic forms of expression of the rejection of the author`smodern reality;

- Myth-making, the implementation of the ancient myths in the poetic text, uniting the myth about Endymion, the myth about Love of Venus and Adonis, and several legends about Glaucus and Pan;

- Search for new artistic forms of reflection of the multidimensionality of the world: romantic maximalism, pantheism, romantic irony; mixing of genre forms: legends, myths, fairy tales, anthem (Hymns devoted to Beauty, Pan, Love, Lady Moon, Muse), songs (Indian Girl's song); the desire for universality (the tendency to create a holistic "visual, tactical, material images"; the reproduction of objects in dynamics, overcoming the static nature of the picture of the Universe);

- Ellinization; depiction of antiquity as a standard of aesthetic harmony and antipode of the modern world;

- The poem is marked by the increasing role of emotional beginning and imagination and subjectivity to reveal the inner world of man, his feelings and thoughts;

- Creating images of romantic characters with an active lifestyle. Implementation of a woman's romantic ideal;

- Aesthetization of love. The poet defines love as the main force transforming a human soul. Endymion`s love is distinguished by a romantic cosmism.

- Keats glorifies the power of sleep to escape from reality.

- Poetization of beauty and creation of picturesque pictures of ancient Greek nature and English landscapes.

As for features of early Aestheticism shown in the poem, there are three of them:

- Decorative style and the use of synesthesia (the desire to mix the smell, sound and color).

- Semantic color function when the change of color means a new state in characters` lives or emotions.

- The cult of Beauty. Endymion and the Goddess of the Moon are depicted as a symbol of harmony of physical and spiritual beauty.

Thus the poem "Endymion" is known to represent the interpretation of well-known mythological plot about Endymion in the context of the artistic values of romantic art and early forming Aestheticism.

60 years later the Victorian poet Hugh Donald Barclay (?? - ??) whose name was mentioned only in the documents of bibliographic archive [6, p. 27] and in his book "Orpheus and Eurydice, Endymion, and other poems (1877) [7] attempted to write the continuation of the poem "Endymion" by Keats. The first 
translation of Barclay`s poem "Endymion or The boy who cried for the Moon" (1877) [7, p. 35-60] from the original language made by L. Fomina [8,p.89-122] in 2014 allows us to get acquainted with a new interpretation of the myth that criticizes the romantic version of Keats. Moreover the Victorian poet's version is a challenge to Romanticism on the whole.

The first part of Barclay's poem is an ironic retelling of easily recognizable episodes from Keats's poem. Endymion's sister Peona does not sympathize with her brother, but laughs at him with his sorrow: "If doth ail thee, brother, tell the tale. /Hast thou done aught against the heavenly powers, / That haply justly they incensed be, /Cut short the pinions of the flying hours, /Or filched the wand of wandering Mercury, /Or strayed with Psyche, in the Paphian bowers, /Arousing Cupid's restless jealousy" [7, p. 37-38]. Barclay also sneers at Keats's eternal love theme, "the tale of an immortal's love, /Unheard by great Olympus, far above" [7, p. 42]. Moreover during the ceremonial marriage of Cynthia and Endymion in heaven, there is an atmosphere of humiliating ridicule regarding to the relationship between the goddess and her lover: "Cynthia, beloved queen, we wish you joy / Began the leader of the starry choir,/ To you, and to your gentle shepherd; / We think you might have looked a little higher. / (...) May Jove, with the favor of this pair look down, / For has not he too; felt a lover's pain; / He dare not have unequal matches frown" [7, p. 45]. The characters' social inequality is also emphasized by the author: "unequal matches". The description of the honeymoon is the last idealistic scene reminding the poem of Keats. Further Barclay writes absolutely new story about Endymion`s fate in the Victorian society.

Destroying the romantic love story, created by Keats, Barclay shows the inability of its development in the Victorian era. First of all, the poet emphasizes that the social inequality of the main characters has become the reason for their divorce. Cynthia, who was accustomed to the magnificent life at Olympus, was oppressed by a beggar existence on the earth, and then returned to heaven in the society of immortal gods. The inhabitants of Olympus the poet compares with representatives of the privileged English elite and calls them "a swarm of golden bees" [7, p. 44], "the starry choir" [7, p. 45] and the inhabitants of the Earth (shepherds, Endymion and his sister Peon),representing the lowest and poorest social layer of England of the nineteenth century are called "miserable mortals" [7, p. 50]. The inhabitants of the Earth have no rights for eternity and paradise. Therefore, Jupiter forbids Endymion, a poor shepherd to stay at Olympia and threatens to punish him for his unauthorized penetration. The episode of so called "expulsion" of Endymion from paradise demonstrates the humiliation of the character by the gods identified with the upper class of Victorian society: "I (Endymion) pushed my head forward / In search of a grove, where I loved to wander"'[7,p.51]. Cynthia forgets about Endymion`s existence.

So he suffered from a bitter loneliness on the earth: "Tired and sad he moaned" [7, p.53]. Endymion was in despair like a "wounded deer" [7, p.53]. His last words before his suicide are full of pain and disappointment in his beloved Cynthia: "The Cold Goddess, you brought me to the grave, / You laugh at me, I die without (...) love" [7, p. 58]. The epitaph on his tombstone says: "Endymion is here, / $\mathrm{He}$ died so early through love to the changing Lady-Moon"[7,p.60]. Thus, the ancient hymn of love from Keats's poem is transformed into a tragedy. Barclay creates a drama, attracting the reader's attention to the cruel reality and the collapse of romantic illusions in the Victorian society. Barclay`s Endymion dies. Thereby the poet declares about the end of the era of 
romantic illusions and proclaims the beginning of the era of pragmatism, which destroys Poetry and Beauty and sincere Love.

Barclay's interpretation is characterized by features of Neomythologism:

- An active transformation of the myth about Endymion through a plot-mediator (Keats`s poem);

- Creating "an alternative variant of the fate" of the character [9,p. 211];

- "Parodying the central situations and characters of the myth" $[9, p .211]$ toactualize the contrast between dream and reality;

- Actual (psychological, political, historical) motivation of characters' actions, which, according to V.A. Andreeva, is considered as deconstruction of "the absolute reality of the myth" [10, p. 282];

- Creation of new (other than in the myth) "eternal values", which desacralize mythological [10, p. 319]. Barclay's poem interprets the myth about Endymion in the context of new historical conditions of the Victorian society when the world is guided by a pragmatic view about things and relationships and leads to rethinking of values;

- Mythological semantics and the real life coexist so the story becomes "non-linear and the time is cyclical" [11, p.52];

- Barclay's version reveals a certain social conflict associated with the class differentiation: the goddess $\leftrightarrow$ shepherd;

- Vision of reality in the poem is "as essentially disharmonious, hopelessly chaotic" [11, p. 46]. Endymion is in a desperate state. Only death allows him to get rid of his suffering for love;

- The image of Endymion has been radically transformed. Instead of the Keats's romantic character with active social lifestyle Barclay depicts a miserable, weak, frustrated shepherd who commits suicide.

Thus, the uniqueness of the Barclay`s version is its neomythological character.

The main artistic features and features of the poem also include: the allusion of the famous Keats`s literary work; a mixture of traditional genre varieties, modified by the author (myth, poem, drama), as an expression of "the desire of neomythologic art to synthesis" [11, p. 47]; psychological and social motivation of actions of characters; striving for psychology, showing changes in Endymion's consciousness (from happiness to disappointment), spiritual emptiness, loneliness as a state of lost hope; the death of Endymion symbolizes collapse of romantic dreams and illusions in new sociohistorical conditions of England at the end of the nineteenth century; criticism of the Victorian society; the apocryphal continuation of the Keats`s plot with elements of its parody.

Thus this article is believed to open the prospects for further consideration of literary endymionade in particular Barclay`s literary heritage.

\section{REFERENCES}

1. Niamtsu, A., 1999. The poetics of traditional plots. Chernivtsy, Ruta, pp: 176

2.

Agapiou, N., 2005. Endymion au carrefour. La fortune littéraire et artistique du my the d'Endymion à l'aube de l'ère moderne. Ikonographische Repertorien zur Rezeption des antiken Mythos Europa, Bei heft IV.Gebr. Mann Verlag, pp: 286

3.

Fomina, L.V., 2014.The interpretation peculiarities of the ancient myth about Endymion in English poetry of the XIX-th century, M. S. thesis, Dnipropetrovsk National 
State Univ. named after Oles Honchar., 10 Dnipropetrovsk, MI, pp: 281.

4.

Keats, J ., 2010. Endymion . Keats` Poetry: 4 Books. The Poetry of John Keats: Lamia, Endymion, Poems 1817 and Poems 1820. The Pennsylvania State University: A Penn State Electronic Classics Series Publication, pp: 27144.

5.

Berkovsky, N. Ya., 2002. Lectures and articles on foreign literature. St. Petersburg: Classical Alphabet, pp: 480.

6.

Reilly, C. W., 2000. Mid-Victorian Poetry, 1860-1879: An Annotated Bibliography. London-New York: Continuum International Publishing Group, pp:560.

7.

Barclay, H. D., 1877. The boy who cried for the Moon. Orpheus and Eurydice, Endymion and other poems. London: Printed by Vincent Brooks. Hardwicke \&Bogue,pp:35-60.

8.

Fomina, L.V., 2014. Endymonade in English poetry of the nineteenth century and its source, Dnipropetrovsk: Advert, pp:144.

9.

Gutsol, S.Yu., 2006. Some features of the reception of neomythologism in the postmodern period. News of the National Technical University of Ukraine: Phylosophy. Psychology. Pedagogy. No. 3.Date Views 10.07.2018.http://www.nbuv.gov.ua/ portal/soc_gum/VKPI_fpp/20063/05_Gucol.pdf
Andreeva, V.A., 2009. Text and discourse parameters of the literary narrative (on the material of modern German-speaking prose). M. S. thesis, St. Petersburg, MI.pp:361.

11.

Pudovochkina, N.E., 2005.Neomifologizm in the artistic culture of the USA of the 20th century. M. S. Thesis, Saransk, MI.pp:160.

OPEN EUROPEAN ACADEMY OF PUBLIC SCIENCES International scientific publishing house 


\title{
Литературная дуэль: Барклей против Китса в контексте перевода малоизвестной поэмы
}

\author{
к.ф.н., доцент Людмила Вячеславовна Фомина
}

\author{
Национальный технический университет Днепровский политехнический университет - \\ НТУУП, \\ пр. Дмитрия Яворницкого, 19, Днепр, 49000, Украина
}

\begin{abstract}
Аннотация:
Исследуются две интерпретации мифологического сюжета об Эндимионе. Английскую поэзию девятнадцатого века отличает интерпретационное разнообразие мифа об Эндимионе. Китсовский Эндимион - это романтический персонаж, который ищет свой идеал красоты и любви, воплощенный в Богине Луны. У Барклея Эндимион слаб. Его самоубийство символизирует крах романтических идеалов в условиях викторианского общества. Что касается образа самой Богини Луны, то в поэме Китса она - идеал женственности, страсти, духовной и физической красоты. По версии Барклея, Богиня Луны изображена как прагматичная, эгоистичная натура, красавица, представляющая элиту общества. Насладившись молодостью и красотой бедного пастуха, она бросает его на произвол судьбы ради роскошной жизни на Олимпе. Интерпретация Барклея рассматривается как критика романтических идеалов и романтизма в целом. Особый интерес представляет украинский (первый с языка оригинала) перевод поэмы Барклея. Открытие малоизвестного английского поэта Дональда Хью Барклея и попытка изучить его творчество дают возможность ввести новое имя в литературную критику.

Данная статья открывает перспективы для дальнейшего изучения литературной эндимионады.
\end{abstract}

Ключевые слова: Миф, Эндимион, Богиня Луны, Трансформация, Интерпретация, Романтизм, Неомифологизм, Эндимионада

\section{Літературна дуель: Барклей проти Кітса в контексті перекладу маловідомої поеми}

к.ф.н., доцент Людмила В'ячеславівна Фоміна, Україна

Національний технічний університет Дніпровський політехнічний університет - НТУУП, пр. Дмитра Яворницького, 19, Дніпро, 49000, Україна 